\author{
(online) $=$ ISSN $2285-3642$ \\ ISSN-L = 2285 - 3642 \\ Journal of Economic Development, Environment and People \\ Volume 2, Issue 3, 2013 \\ URL: http://jedep.spiruharet.ro \\ e-mail: office jedep@spiruharet.ro
}

\title{
Influence of Fertilization System on Wheat Yields in Terms of Global Climate Change
}

\author{
Miroslav Jelić ${ }^{1}$, Olivera Nikolić ${ }^{3}$, D. Knežević ${ }^{1}$, Nadica Savić ${ }^{1}$, G. Dugalić ${ }^{2}$ \\ ${ }^{1}$ University of Priština, ${ }^{2}$ University of Kragujevac, ${ }^{3}$ EDUCONS University, Serbia
}

\begin{abstract}
.
Over the last few decades, wheat production, both in Serbia and worldwide, has been practiced under characteristic agro-meteorological conditions. It has generally been affected by specific strongly marked agrometeorological and climate extremes, most notably extreme temperature and drought events during critical periods in the growing season, which mostly had a negative impact on the growth, development and yield of wheat in Central Serbia.

This paper presents results and discussion on both the potential effect of climate change on winter wheat yield and the possibility to alleviate it through an appropriately adjusted fertilization system.

The present study on the effect of different rates and ratios of NPK fertilizers on grain yield in seven winter wheat cultivars under different (dry and "normal") conditions during the year was conducted in a long-term field experiment at the Small Grains Research Centre in Kragujevac over a period of seven years (2000/01-2006/07).

Depending on the fertilization treatment, the average yield reduction in dry years showed $50 \%$ variation relative to "normal" years. The highest reduction in grain yield and other productive traits of wheat in dry years was observed in the treatment involving nitrogen nutrition, particularly lower application rates. As compared to the non-treated control, the use of complete NPK fertilization having an increased amount of phosphorus resulted in the lowest yield reduction during the dry years that were unfavorable for winter wheat production. The average grain yield reduction in dry years was lowest in wheat cultivar Matica and highest in Kg-100, respectively.
\end{abstract}

Keywords: Cultivar, fertilization, global climate change, yield, wheat.

JEL Codes: Q54, 013

\section{Introduction}

Over the last several decades, a frequent occurrence of extreme weather and climate events has been observed, leading to devastating effects on human society and the environment. These extremes have been induced by changes in meteorological elements (air temperature, rainfall amount and spatial distribution, wind speed and direction, cloudiness occurrence, amount of solar radiation etc.) and have a direct effect on the intensity and duration of meteorological events (a higher frequency of occurrence of heat waves, droughts, bad weather etc.).

Wheat production in Central Serbia has been practiced under characteristic agro-meteorological conditions in the past decade. The overall plant production during the period has been affected by specific strongly marked climate and agro-meteorological extremes. High positive deviations of monthly air 


\author{
(online) $=$ ISSN $2285-3642$ \\ ISSN-L = $2285-3642$ \\ Journal of Economic Development, Environment and People \\ Volume 2, Issue 3, 2013 \\ URL: $\underline{\text { http://jedep.spiruharet.ro }}$ \\ e-mail: office jedep@spiruharet.ro
}

temperatures have been observed, most particularly during certain months of the winter (January and February) and summer (July and August) seasons. Moreover, long periods of extremely high air temperatures (10-17 days) and soil and air drought are characteristic of the period (Savić et al., 2009; Paunovic et al., 2010).

These weather conditions, particularly extreme temperature and drought events during critical stages of the growing season, have mostly adversely affected the growth, development and yield of not only wheat but also of most other crops (Josipović et a., 2005; Savić et al., 2009; Maklenović et al., 2009; Stanković et al., 2009; Paunović et al., 2010).

The objective of this study was to test variations in winter wheat yield over the years in Central Serbia with a particular focus being placed on the effects of precipitation and temperature regimes.

\title{
2. Material and method
}

The meteorological data (precipitation and mean air temperatures) for Kragujevac were obtained from the National Hydrometeorological Service based in Belgrade. The region selected for the evaluation of the effect of weather on winter wheat yields was Central Serbia - Kragujevac or Sumadija (total area 1600 km2). The study was carried out at the Small Grains Research Centre in Kragujevac in a stationary field trial involving fertilization over a period of seven years from 2001 to 2007.

The research included an untreated control and the following combined fertilization treatments: N1 (80 kg N ha-1); N2 (120 kg N ha-1); P1 (60 kg P2O5 ha-1); P2 (100 kg P2O5 ha-1); K (60 kg K20 ha-1). The trial was set up in a randomized block design with three replications. Experimental plot size was $100 \mathrm{~m} 2$ for fertilization with $\mathrm{P}$ and $\mathrm{K}$. The plot was divided into two subplots of $50 \mathrm{~m} 2$ each for two $\mathrm{N}$ application rates. The winter wheat (Triticum aestivum L.) cultivars used in the trial were Takovčanka, Studenica, Kg- 56, Kg100, Toplica, Matica and Lazarica. Wheat was cultivated in rotation with millet. The rest of the production technology employed was conventional. The crop was harvested at full maturity, and grain yield was measured and adjusted to $14 \%$ moisture.

The soils of Šumadija have limited fertility, mainly due to their less favorable physical and chemical properties. Major factors that constrain soil fertility include acid reaction, nutritional imbalances, low levels of available phosphorus (P) and unfavorable physical properties (Milivojević et al., 2008).

\section{Results and discussion}

Wheat yield is mostly dependent upon meteorological conditions during the growing season, notably precipitation and temperature. Along with soil, climate is a factor determining the choice of an adequate cultivation system, cultivar, cultural operations and fertilization method. 


\author{
(online) = ISSN $2285-3642$ \\ ISSN-L = $2285-3642$ \\ Journal of Economic Development, Environment and People \\ Volume 2, Issue 3, 2013 \\ URL: http://jedep.spiruharet.ro \\ e-mail: office jedep@spiruharet.ro
}

Major climate elements that limit wheat production in Central Serbia are precipitation and temperatures. Therefore, water is an important factor in plant development due to its fundamental role in numerous life processes in the plant. Water deficiency during stem elongation and heading as the two critical stages of wheat development is found to be a constraint to high yields.

The agro-climatic analyses performed as part of this research involved investigation, collection, verification, analysis and interpretation of major climatic parameters which were thereafter used in the evaluation of the productivity and adaptability of wheat genotypes to climatic stress factors. Data on the amount of precipitation during the critical period of the winter wheat growing season (March-June) across months as compared to the long-term mean (1961-1990) are given in Tab. 1. Quite different amounts and distribution of precipitation were observed in the wheat growing seasons. The third, fourth and seventh years of the study were characterized by substantially reduced total precipitation amounts (196.0-265.7 $\mathrm{mm}$ ) and highly uneven distribution of precipitation during the evaluated part of the growing season as compared to the long-term mean and the other years analyzed (2001, 2002, 2005 and 2006) (Tabs. 1 and 2). Furthermore, apart from the insufficient amounts of precipitation in the critical stages of wheat development during 2003, 2004 and 2007, which were found to be less favorable i.e. unfavorable for plant development, this period was also characterized by increased mean monthly air temperatures as compared to the long-term mean and the other years analyzed (Tab. 1).

The average grain yield of winter wheat ranged from 2.65 to $5.19 \mathrm{t}$ ha-1 depending on the year i.e. weather conditions (precipitation and temperature). During the years that were less favorable for wheat development, a considerably lower grain yield of winter wheat (3.24 t ha-1) was obtained, as compared to the other years analyzed.

Table 1: Winter wheat yields and weather data variations in Kragujevac for the 2001-2007 period

\begin{tabular}{|c|c|c|c|c|c|c|c|c|c|c|c|}
\hline \multicolumn{12}{|c|}{ Winter wheat grain yield in the region of Kragujevac and weather characteristics } \\
\hline \multirow{3}{*}{ Year } & \multirow{3}{*}{$\begin{array}{l}\text { Grain } \\
\text { yield of } \\
\text { wheat }\end{array}$} & \multicolumn{10}{|c|}{ Precipitation $(\mathrm{mm})$ and mean air temperatures $(\mathrm{OC})$} \\
\hline & & \multicolumn{2}{|c|}{ March } & \multicolumn{2}{|c|}{ April } & \multicolumn{2}{|c|}{ May } & \multicolumn{2}{|c|}{ June } & \multicolumn{2}{|c|}{ July } \\
\hline & & $\mathrm{mm}$ & $\mathrm{OC}$ & $\mathrm{mm}$ & OC & $\mathrm{mm}$ & OC & $\mathrm{mm}$ & OC & $\mathrm{mm}$ & $\mathrm{OC}$ \\
\hline 2001 & 5.19 & 36.8 & 11.0 & 155.3 & 10.8 & 44.5 & 17.4 & 109.1 & 18.5 & 59.4 & 23.1 \\
\hline 2002 & 4.16 & 26.0 & 8.9 & 63.7 & 10.8 & 38.6 & 18.4 & 57.2 & 21.6 & 99.5 & 23.3 \\
\hline 2003 & 2.75 & 2.8 & 5.8 & 37.2 & 10.8 & 42.3 & 19.9 & 47.7 & 23.3 & 66.0 & 22.5 \\
\hline 2004 & 3.28 & 21.3 & 7.1 & 52.3 & 12.8 & 50.3 & 14.5 & 61.4 & 19.8 & 80.4 & 22.0 \\
\hline 2005 & 4.74 & 44.5 & 4.7 & 69.0 & 11.6 & 70.2 & 16.5 & 50.8 & 19.3 & 86.2 & 21.7 \\
\hline 2006 & 4.65 & 116.1 & 6.0 & 86.3 & 12.7 & 29.1 & 16.6 & 84.8 & 19.8 & 22.4 & 23.1 \\
\hline 2007 & 3.68 & 62.9 & 9.1 & 3.6 & 12.1 & 119.2 & 18.3 & 25.3 & 22.9 & 10.1 & 24.8 \\
\hline \multicolumn{2}{|c|}{$X$} & 44.3 & 7.5 & 66.8 & 11.6 & 56.3 & 17.4 & 62.3 & 20.7 & 60.6 & 22.9 \\
\hline \multicolumn{2}{|c|}{ Means 1961-1990 } & 40.0 & 6.7 & 55.0 & 11.2 & 64.0 & 16.2 & 68.0 & 19.9 & 69.0 & 21.1 \\
\hline
\end{tabular}




\author{
(online) = ISSN $2285-3642$ \\ ISSN-L = 2285-3642 \\ Journal of Economic Development, Environment and People \\ Volume 2, Issue 3, 2013 \\ URL: $\underline{\text { http://jedep.spiruharet.ro }}$ \\ e-mail: office jedep@spiruharet.ro
}

The decrease in wheat yield during the three years also resulted from unfavorable weather conditions, involving particularly reduced precipitation amounts in the critical stages of winter wheat development. The total sum of precipitation in the period analyzed during the less favorable years was below $300 \mathrm{~mm}$ and $48 \%$ lower on average as compared to the years having favorable weather conditions (Tabs. 1 and 2).

The lowest average grain yield of winter wheat was obtained in the year 2003 characterized by the lowest sum of precipitation (196 mm) over the period analyzed (Tab. 2). The very low amounts of precipitation in the growing season, particularly in March $(2.8 \mathrm{~mm})$, which were quite below the long-term mean, along with the lack of precipitation during April, had an unfavorable effect on further wheat crop development. The deficiency of precipitation and the resulting strong soil desiccation induced very low nitrogen mobilization from soil reserves and led to decreased utilization of this nutrient from the nitrogen fertilizers applied following wheat fertilization (Stanković, 2010).

The 2007 growing season was marked not only by reduced amounts of precipitation but also by increased air temperatures, most notably in the second part of the wheat growing season. The high air temperatures during this part of the growing season caused continuous accumulation of effective temperatures above $50 \mathrm{C}$ as well as increased soil temperatures at the root zone, leading to much earlier succession of plant developmental stages than commonly observed under Serbian climate conditions. Generally, such weather conditions, along with strongly marked extreme temperature and drought events in critical periods of the growing season, had an adverse effect on the growth and development and, eventually, grain yield and quality of wheat.

The highest sum of precipitation in the period analyzed (March-July) was in 2001 (405.1 mm), when the average grain yield produced was $5.19 \mathrm{t}$ ha-1. The growing season in this year was quite favorable in terms of soil moisture reserves required for the mineralization of both organic residues and the mineral fertilizers applied. During the growing season, precipitation distribution was observed to be quite uneven. However, the amounts of precipitation in March and April were considerably above the long-term mean and had a favorable effect on tailoring intensity and growth of wheat plants. Therefore, the conditions existing during wheat fertilization were highly favorable for nitrogen mobilization and utilization from the nitrogen fertilizers applied. Weather conditions were favorable for wheat plant development both during the heading and grain filling periods. Similar results were previously obtained by Savić et al. (2009); and Stanković et al. (2010).

A positive effect on grain yield stability in wheat plants was obtained by increased fertilizer rates, particularly during the years when weather conditions were unfavorable for wheat production (Tab. 2). During the years having favorable weather conditions (2001, 2002, 2005, 2006), NPK fertilization led to a yield increase as compared to the control, the increase being 2.7-fold and 2.9-fold higher at lower (N1) and higher (N2) nitrogen rates applied, respectively. 


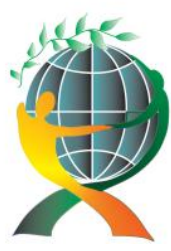

\author{
(online) = ISSN $2285-3642$ \\ ISSN-L = 2285 - 3642 \\ Journal of Economic Development, Environment and People \\ Volume 2, Issue 3, 2013 \\ URL: http://jedep.spiruharet.ro \\ e-mail: office jedep@spiruharet.ro
}

Table 2: Wheat yields and weather characteristics

\begin{tabular}{|c|c|c|c|c|c|c|c|c|c|c|c|c|c|}
\hline \multicolumn{14}{|c|}{ Precipitation, temperatures and winter wheat grain yield in the region of Kragujevac } \\
\hline \multirow{3}{*}{ Year } & \multicolumn{2}{|c|}{ SP } & \multicolumn{11}{|c|}{ Fertilization treatment } \\
\hline & \multirow{2}{*}{$\stackrel{P}{P}$} & \multirow{2}{*}{$\left.{ }^{\mathrm{T}} \mathrm{OC}\right)$} & \multirow{2}{*}{$\mathrm{O}$} & \multicolumn{2}{|c|}{$\mathrm{N}$} & \multicolumn{2}{|c|}{ NP1K } & \multicolumn{2}{|c|}{ NP2K } & \multicolumn{2}{|c|}{ NP1 } & \multicolumn{2}{|c|}{ NK } \\
\hline & & & & N1 & N2 & N1 & N2 & N1 & N2 & N1 & N2 & N1 & N2 \\
\hline 2001 & 405.1 & 16.2 & 2.69 & 4.14 & 4.32 & 4.89 & 5.08 & 6.67 & 7.04 & 6.30 & 6.37 & 4.81 & 4.41 \\
\hline 2002 & 285.0 & 16.6 & 1.94 & 3.98 & 4.04 & 4.28 & 4.89 & 5.02 & 5.10 & 4.93 & 5.29 & 4.05 & 3.09 \\
\hline 2003 & 196.0 & 16.5 & 1.10 & 2.88 & 3.24 & 2.88 & 3.04 & 2.86 & 3.25 & 2.75 & 3.05 & 2.61 & 2.98 \\
\hline 2004 & 265.7 & 15.2 & 1.23 & 2.98 & 3.89 & 3.29 & 3.56 & 3.98 & 4.05 & 3.07 & 3.41 & 3.38 & 3.58 \\
\hline 2005 & 320.7 & 14.8 & 2.21 & 4.16 & 4.42 & 4.66 & 4.98 & 6.28 & 6.39 & 5.23 & 5.82 & 4.24 & 3.91 \\
\hline 2006 & 338.7 & 15.6 & 2.02 & 4.08 & 4.26 & 4.70 & 4.88 & 6.23 & 6.98 & 4.15 & 4.43 & 4.88 & 4.82 \\
\hline 2007 & 221.1 & 17.4 & 1.62 & 3.50 & 3.61 & 3.66 & 3.98 & 4.25 & 4.51 & 3.87 & 4.35 & 3.61 & 3.78 \\
\hline$X$ & 290.3 & 16.0 & 1.84 & 3.67 & 3.97 & 4.05 & 4.34 & 5.04 & 5.33 & 4.33 & 4.67 & 3.94 & 3.79 \\
\hline
\end{tabular}

SP-sums for the March-July period, P-precipitation, T- mean monthly temperatures, $\mathrm{X}$ - average

During the years that were less favorable for wheat production $(2003,2004,2007)$, the use of NPK fertilizers, especially those having increased amount of phosphorus (NP2K), as compared to the control, gave a 2.8-fold and 3.0-fold average yield increase at the lower and higher nitrogen rates applied, respectively. The increasing phosphorus fertilization rates applied in the years having unfavorable weather conditions resulted in higher wheat production stability as compared to the treatment employing lower or no rates of phosphorus. The lower decline in wheat yield at higher phosphorus fertilization rates used in the years unfavorable for wheat production was also previously reported (Boeye et al., 1999).

Higher nitrogen rates (120 kg ha-1) had a stronger effect on wheat yield increase except in the NK treatment during all years (Tab. 2). In the treatment using only nitrogen, a higher effect of the increasing $\mathrm{N}$ rate was observed in the years that had less favorable weather conditions, as opposed to the other fertilization treatments.

The yield of the winter wheat cultivars tested showed variations depending also on weather conditions during the research period (Tab. 3). The lowest grain yield was obtained by cv. Kg 100 (4). So, the average grain yield of this cultivar, during the years that were less favorable for wheat production, was low $(2.85 \mathrm{t}$ ha-1). 


\author{
(online) $=$ ISSN $2285-3642$ \\ ISSN-L = 2285 - 3642 \\ Journal of Economic Development, Environment and People \\ Volume 2, Issue 3, 2013 \\ URL: http://jedep.spiruharet.ro \\ e-mail: office jedep@spiruharet.ro
}

Table 3: Effect of precipitation and mean air temperatures on wheat cultivar yields

\begin{tabular}{|c|c|c|c|c|c|c|c|c|c|}
\hline \multicolumn{10}{|c|}{ Precipitation, temperatures and winter wheat grain yield in the region of Kragujevac } \\
\hline \multirow[t]{2}{*}{ Year } & \multicolumn{2}{|c|}{ Annual sum } & \multicolumn{7}{|c|}{ Sorte } \\
\hline & $\mathrm{mm}$ & OC & 1. & 2. & 3. & 4. & 5. & 6. & 7. \\
\hline 2001 & 824.6 & 12.0 & 5.19 & 4.89 & 4.89 & 5.05 & 4.39 & 5.36 & 4.82 \\
\hline 2002 & 638.3 & 12.5 & 3.88 & 4.05 & 3.56 & 3.43 & 4.21 & 3.96 & 4.36 \\
\hline 2003 & 478.1 & 12.0 & 2.38 & 2.51 & 2.44 & 2.15 & 2.98 & 3.10 & 2.96 \\
\hline 2004 & 709.9 & 11.7 & 3.12 & 3.35 & 3.10 & 3.05 & 3.16 & 3.66 & 3.52 \\
\hline 2005 & 809.3 & 11.0 & 4.23 & 4.90 & 5.21 & 4.75 & 4.22 & 4.79 & 5.02 \\
\hline 2006 & 691.1 & 11.8 & 4.20 & 4.65 & 4.67 & 4.15 & 4.77 & 5.25 & 4.82 \\
\hline 2007 & 640.6 & 12.9 & 3.54 & 3.45 & 3.63 & 3.35 & 3.52 & 4.05 & 3.86 \\
\hline Average & 684.5 & 12.0 & 3.79 & 3.97 & 3.93 & 3.70 & 3.89 & 4.31 & 4.19 \\
\hline
\end{tabular}

The highest grain yield in all years excepting 2005 was obtained by cv. Matica (6). In addition, during the years that were less favorable for wheat production, this cultivar had the highest average grain yield, which was $3.60 \mathrm{t}$ ha-1 over the three-year period. At unfavorable weather conditions, grain yield of cv. Matica was for 26\% higher in relation to grain yield of cv. Kg 100.

\title{
4. Conclusions
}

In the analyzed period, the meteorological conditions had a significant effect on the grain yield of winter wheat produced in Central Serbia. The marked deficiency of precipitation and high air temperatures during the growing seasons of 2003 through 2005 induced a significant reduction in winter wheat yield.

During less favorable and unfavorable years, the use of a complete NPK fertilizer, most notably increased phosphorus rates, reduced the adverse impact of unfavorable weather events on wheat grain yield.

The negative effect of drought and high air temperatures on winter wheat productivity can be mitigated by an adequate choice of drought-tolerant and early maturing cultivars that pass through a series of phenophases more rapidly, thus avoiding the stress factors of unfavorable weather. The highest tolerance to unfavorable weather conditions during winter wheat production was observed in cv. Matica. 


\author{
(online) $=$ ISSN $2285-3642$ \\ ISSN-L = $2285-3642$ \\ Journal of Economic Development, Environment and People \\ Volume 2, Issue 3, 2013 \\ URL: http://jedep.spiruharet.ro \\ e-mail: office jedep@spiruharet.ro
}

\title{
5. References
}

[1] Boeye, D., Verhagen, B., Van Haesebroeck, 1. V. and El-Kahloum, M. (1999). Phosphorus fertilization in a phosphorus-limited fen: effect of liming. Applied vegetation science, 2(1), 71-78.

[2] Josipović, M., Kovačević, V., Petošić, D. and Šoštarić, J. (2005). Wheat and maize yield variations in the BrodPosavina area. Cereal Research Communications, 33(1), 229-233.

[3] Maklenović, V., Vučković, S., Kovačević, V., Prodanović, S., Živanović, Lj. (2009). Precipitation and temperature regimes impacts on maize yields. In: Proceedings of the XLIV Croatian Symposium on Agriculture with Internacioanal Participation (Loncaric Z. And Maric S. Eds.), 16-20 February, Opatija, Croatia, pp. 569-573.

[4] Milivojević, J., Jelić, M., Đalović, I., Komljenović, I. (2008). Impact of fertilization on iron, manganese and zinc ststus in oats grown on vertisol of Serbia. Research Communications, 36(2), 255-258. Novak, A. and Erdelyi, E. (2010). How barley growing conditions and its output change in Hungary. Agricultural Informatics, 1(2), 1-7.

[5] Savić, N., Jelić, M., Knežević, J., Knežević, D. (2009). Analiza vremenskih uslova u proizvodnji ozime pšenice na području centralne Šumadije. Zbornik radova, XIV Savetovanje o biotehnologiji sa međunarodnim učešćem. Agronomski fakultet Čačak, 59-65.

[6] Stanković, S. (2010). Uticaj azota na proizvodnju pšenice na različitim tipovima zemljišta. Doktorska disertacija. Poljoprivredni fakultet. Zemun, 141.

[7] Paunović, A., Kovačević, V., Madić, M., Jelić, M., Iljkić, D. (2010). Uticaj vremenskih prilika na prinose pšenice u periodu 2000.-2007. godine. Zbornik radova, XV Savetovanje biotehnologiji sa međunarodnim učešćem. Agronomski fakultet Čačak, 29-37. 
(online) $=$ ISSN $2285-3642$

ISSN-L = 2285 - 3642

Journal of Economic Development, Environment and People

Volume 2, Issue 3, 2013

URL: $\underline{\text { http://jedep.spiruharet.ro }}$

e-mail: office jedep@spiruharet.ro 